
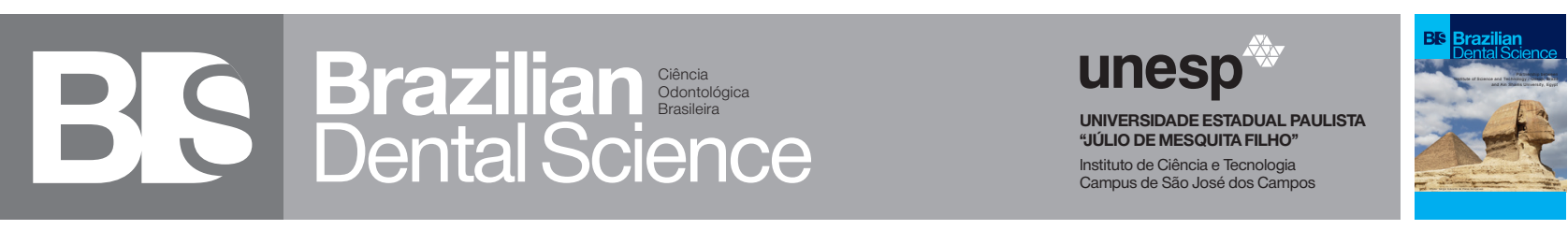

\title{
Effect of mentoplasty on esthetic perception of dental surgeons, dental students and lay persons
}

Efeito da mentoplastia na percepção estética de cirurgiões-dentistas, estudantes de odontologia e leigos

Matheus Melo PITHON ${ }^{1}$, Diego Oliveira GUEDES ${ }^{1}$, Solane Domingues LEAL ${ }^{1}$,Maria Luiza Anselmo da SILVA ${ }^{1}$, Raphaela Rodrigues DANTAS $^{1}$, Ketlly Cruz da Cunha PELEGRINI ${ }^{1}$, Raildo da Silva COQUEIRO ${ }^{2}$

1 - Southwest Bahia State University ( UESB) - Vitória da Conquista - BA - Brazil.

2 - Federal University of Santa Catarina (UFSC) - Florianópolis - SC - Brazil.

\section{ABSTRACT}

Objective: was to evaluate the influence of mentoplasty on esthetic perception of dental surgeons, dental students and lay persons. In addition, to determine whether the outstanding chin affects the perceived desire for orthognathic surgery. Material and Methods: An image of an ideal silhouette was created. This image was manipulated to create another six images with different degrees of retrogenia and progenia in increments, advancing and receding the chin on a scale of $5 \mathrm{~mm}$ (from +15 to $-15 \mathrm{~mm}$ ) in the anteroposterior and vertical directions. Once the images were obtained, a questionnaire was created, which was evaluated by lay persons, dental surgeons and dental students ( $\mathrm{n}=$ 50). The evaluators used a visual analog scale to analyze the images, establishing a score ranging from 0 to 10 . Associated with the scale, the evaluators were asked whether they wished to have some surgical correction performed if the image in question were a representation of their own facial profile. Results: demonstrated that image $\mathrm{H}(0 \mathrm{~mm})$ was ranked as the most attractive by the dental surgeons, while the dental students and lay persons scored B $(-5 \mathrm{~mm})$ as the best image. In general, images A ( $+15 \mathrm{~mm})$ and D $(-15 \mathrm{~mm})$ were those that most induced a desire for corrective surgery. Conclusion: the prognathic and retrognathic facial profiles were unpleasant and perceptible to the dentist, dental student and lay person. The more projected and retracted the chin was, the greater was the desire to have orthognathic surgery performed.

\section{KEYWORDS}

Esthetics; Mentoplasty; Face.

\section{RESUMO}

Objetivo: avaliar a influência da mentoplastia na percepção estética de cirurgiões-dentistas, estudantes de Odontologia e leigos. Além de determinar se o destaque do mento afeta o desejo percebido por cirurgia ortognática. Material e Métodos: a imagem de uma silhueta ideal foi manipulada para criar outras seis imagens com diferentes graus de retrogenia e progenia em incrementos, avançando e recuando o mento numa escala de $5 \mathrm{~mm}$ (de +15 a $-15 \mathrm{~mm}$ ) nos sentidos ântero-posterior e vertical. De posse dessas imagens criou-se um questionario que foi avaliado por leigos, Cirurgiões-Dentistas e estudantes de Odontologia $(n=50)$. Os avaliados utilizaram uma escala visual analógica para analisar as imagens, estabelecendo nota que variam de 0 a 10 . Associado a escala os avaliadores foram questionados se eles teriam vontade de realizar alguma correção cirúrgica caso aquela imagem representasse o seu próprio perfil facial. Resultados: demostraram que a imagem $\mathrm{H}$ (0 $\mathrm{mm}$ ) foi ranqueada como a mais atratativa pelos cirurgiões dentistas, enquanto os estudantes de odontologia e pessoas leigas pontuaram a B $(-5 \mathrm{~mm})$ como a melhor. De forma geral, as imagens A $(+15$ $\mathrm{mm})$ e $\mathrm{D}(-15 \mathrm{~mm})$ foram as que mais induziram o desejo por cirurgia corretiva. Conclusão: o perfil facial prognata e retrognata é desagradável e perceptível para o dentista, o estudante de odontologia e o leigo. Quanto mais projetado e retruido for o mento maior o desejo pela realização de cirurgia ortognática.

\section{PALAVRAS-CHAVE}

Estética; Mentoplastia; Face. 


\section{INTRODUCTION}

T $\mathrm{n}$ orthodontic treatment, facial harmony $\perp$ and balance, as well as ideal occlusion must be simultaneous and equally important objectives [1]. The contemporary perspective of dental practice and research demands that professionals approximate the expectations of their patients when defining the best facial esthetics as the main objective of the treatment. In order to do this, it is important to understand the patient's dissatisfaction as regards his/her facial pattern, taking into consideration his/ her perception with regard to the esthetics of the face and its relationship with society.[2-4].

The chin, being one of the most apparent and exposed facial structures of the body, is fundamental in the composition of the profile, expressed by the symmetry and harmony of the facial features/traits [5].

The procedures for correction of alterations of the chin are performed with merely esthetic objectives, without significant functional changes [5-7]. In view of this, mentoplasty is a technique that presents great versatility, and can be used for the correction of tridimensional deformities of the chin and as a simpler procedure for masking cases in which there is the presence of mandibular deficiency or excess (threshold cases). In spite of being a routinely performed procedure, with a view to camouflaging malocclusions, there are few studies available in the literature that have been concerned about evaluating the impact of this procedure on facial esthetics from the patient's perspective $[6,7]$.

Based on this premise, the authors' purpose in this study was to evaluate the influence of the position of the chin in different degrees of progenia and retrogenia, and determine whether greater or less emphasis of the chin would affect the perceived desire for orthognathic surgery. In addition the preferences among dental surgeons, dental students and lay persons would be evaluated and the effect of the evaluators' gender on the perception of attractiveness.

\section{MATERIAL AND METHODS}

In order to conduct this study, image manipulation software (Adobe Photoshop ${ }^{\circledR}$ CS6,Adobe Systems Inc., San Jose, CA USA) was used to create the image of a facial profile silhouette with soft tissue proportions and measurements based on criteria at present accepted as being ideal.

Using the same software, the image of the ideal silhouette was manipulated with the purpose of creating another 6 images (Figure 01 ) advancing and retracting the chin on a scale of $5 \mathrm{~mm}$ (from +15 to $-15 \mathrm{~mm}$ ) in the anteroposterior and vertical directions.

Before the study began, the sample calculation was made, which established the need for the study to be conducted with a sample ranging from 120 to 200 individuals. In accordance with this recommendation, 150 individuals were evaluated, these being dental students, dental surgeons and lay persons.

The images were printed on photographic paper and attached to questionnaires. The study was divided into two stages; one in which all the images were presented together, and the next stage in which each image was evaluated separately. In the first stage of the study, in which the evaluators saw all the images together, they were asked whether they were able to note differences between the images, in addition to having to indicate the image they liked best and the one they liked least (Figure 2 a). On a second page, the same images were reorganized randomly (Figure $2 \mathrm{~b}$ ), following the same evaluation as before (stage with a view to evaluating the degree of reliability of the answers given by the observers in the first part of the questionnaire). Next, the 8 images were printed individually, named from $\mathrm{A}$ to $\mathrm{H}$ and attached to the questionnaire (Figure 3). Each image contained scale of attractiveness from 0 (not attractive), 5 (attractive) to 10 (very attractive). Together with the evaluation scale, the evaluators were asked whether, based on the profile presented, he/she would or would not indicate surgical correction, if 
the image concerned were to represent his/ her own facial profile.

The observers were instructed not to compare the images. The evaluation time interval for each image was limited to 45 seconds. This study was approved by the Ethics committee.

The frequencies of the answers given by the dental surgeons, dental students and laypersons were compared by means of the Exact Fisher Test. The mean scores for each image were compared among the groups of participants by means of the Kruskal-Wallis test and a comparison between pairs was performed using the Mann-Whitney test. The Mann-Whitney test was also used to compare the mean scores between the sexes. The association between the desire for corrective surgery and the groups studied was tested by means of the Poisson regression technique. A robust model was calculated adjusted by sex to estimate the prevalence ratio (PR), with its respective interval of confidence of 95\% (IC95\%). The level of significance of 5\% ( $\alpha$ $=0.05$ ) was adopted for all the analyses. The data were tabulated and analyzed using the software programs IBM SPSS 21.0, 2012, Armonk, NY: IBM Corp.).

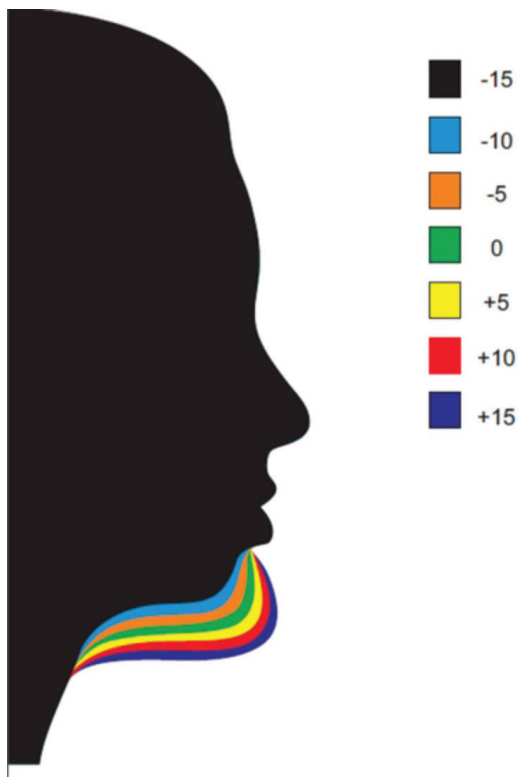

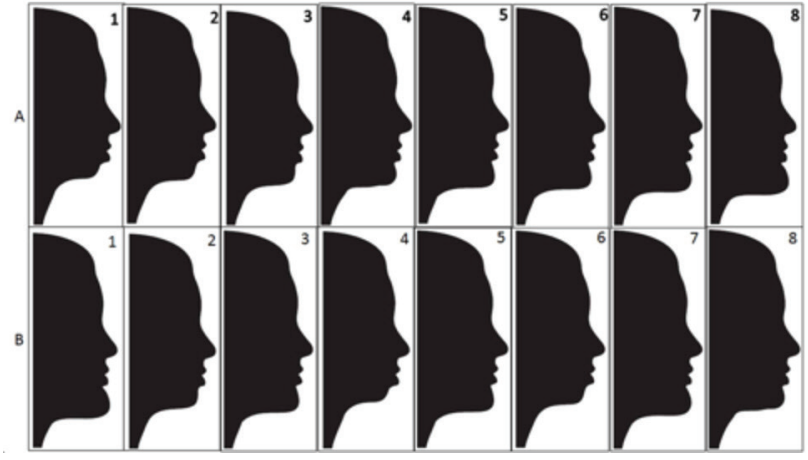

Figure 2 - A- Image $1=-15 \mathrm{~mm}$; Image $2=-10 \mathrm{~mm}$; Image 3 = $-5 \mathrm{~mm}$; Image $4=0 \mathrm{~mm}$; Image $5=+5 \mathrm{~mm}$; Image $6=+5 \mathrm{~mm}$; Image $7=+10 \mathrm{~mm}$; Image $8=+15 \mathrm{~mm}$; B- $1=+15 \mathrm{~mm}$; Image 2 $=-5 \mathrm{~mm}$; Image $3=+5 \mathrm{~mm}$; Image $4=-15 \mathrm{~mm}$; Image $5=+5$ $\mathrm{mm}$; Image $6=-10 \mathrm{~mm}$; Image $7=+10 \mathrm{~mm}$; Image $8=0 \mathrm{~mm}$.

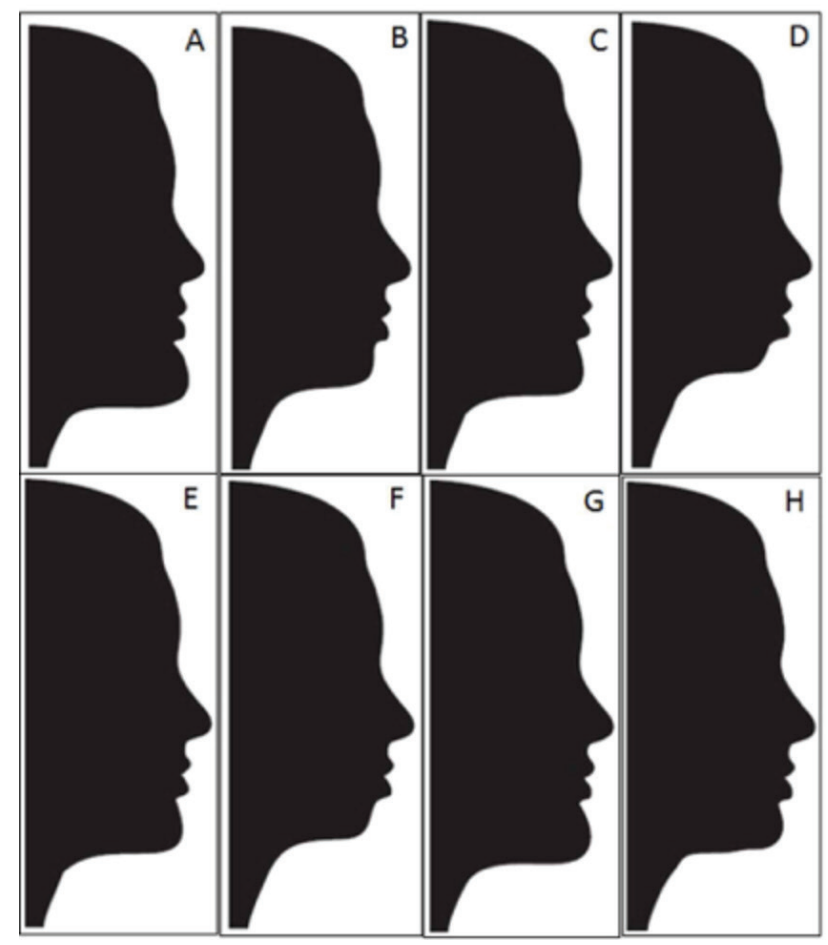

Figure 3 - Image $A=+15 \mathrm{~mm}$; Image $B=-5 \mathrm{~mm}$; Image $C=+5$ $\mathrm{mm}$; Image $\mathrm{D}=-15 \mathrm{~mm}$; Image $\mathrm{E}=+5 \mathrm{~mm}$; Image $\mathrm{F}=-10 \mathrm{~mm}$; Image $\mathrm{G}=+10 \mathrm{~mm}$; Image $\mathrm{H}=0 \mathrm{~mm}$.

Figure 1- Comparison of the modified images. 


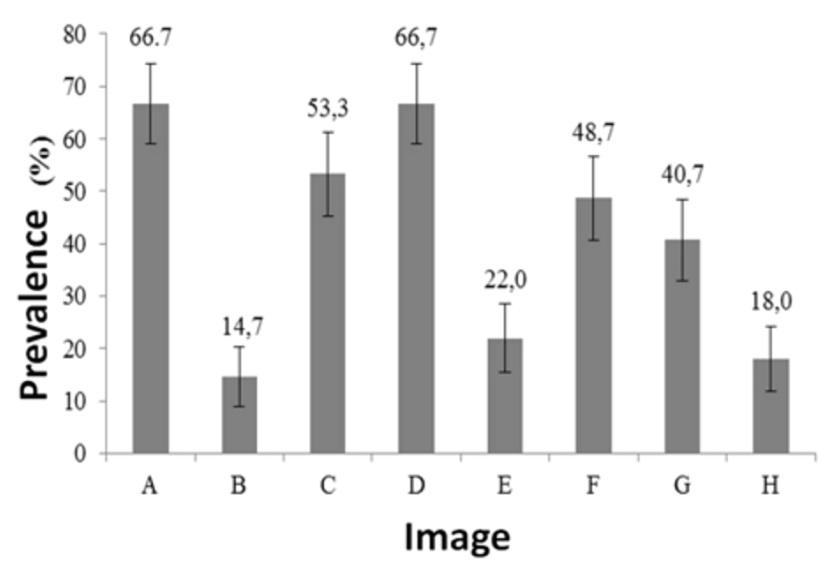

Figure 4 - Prevalence of the desire to undergo corrective surgery, according to the images presented. The error bars represent the interval of confidence at 95\% (IC95\%).

\section{RESULTS}

\section{Analyses of Frequencies}

All the dental surgeons, dental students and laypersons who participated in the study were able to note differences between the images presented in Figure $2 \mathrm{~A}$ and B.

Table 1 presents the perception of the research participants with respect to the preferences with regard to the images presented. The data observed in Table 1 for Figure $2 \mathrm{~A}$ show that there was statistical difference in the proportions among the groups about the most preferred image, but not about the least preferred image. Image $4(0 \mathrm{~mm})$ was elected as the best by the three groups, however, higher frequency of this image being liked most by dental surgeons was observed than by laypersons. Image $8(+15$ $\mathrm{mm}$ ) was the one that least pleased everyone, followed by image $1(-15 \mathrm{~mm})$ but in a lower proportion of displeasure.

In the case of Figure $2 \mathrm{~B}$, there was also statistical difference in the proportions among the groups, about the most preferred image, but not about the least preferred image. Images $8(0$ $\mathrm{mm}), 2(-5 \mathrm{~mm})$ and $6(+5 \mathrm{~mm})$ were elected the best by the dental surgeons, dental students and laypersons, respectively. Image $1(+15 \mathrm{~mm})$ was the one that least pleased everyone, followed by image $4(-15 \mathrm{~mm})$ and image $10(+10 \mathrm{~mm})$ but in a lower proportion of displeasure.

\section{Analyses of mean scores}

The mean scores for each image are shown in Table 2 . Image $\mathrm{H}(0 \mathrm{~mm})$ was ranked as the most attractive by the dental surgeons, while the dental students and laypersons scored B $(-5 \mathrm{~mm})$ as the best image. Image D (-15 $\mathrm{mm}$ ) was scored as the least attractive by the dental surgeons, while the dental students and laypersons scored image $\mathrm{A}(+15 \mathrm{~mm})$ as the worst. The scores attributed to images $\mathrm{C}(+5$ $\mathrm{mm}), \mathrm{D}(-15 \mathrm{~mm}), \mathrm{E}(+5 \mathrm{~mm}), \mathrm{F}(-10 \mathrm{~mm})$ and $\mathrm{G}(+10 \mathrm{~mm})$ presented significant differences among the groups. The comparisons between pairs showed that the laypersons awarded higher scores to image C ( $+5 \mathrm{~mm}$ ), compared with the dental surgeons and dental students; image D $(-15 \mathrm{~mm})$ received better scores from the dental students, compared with the dental surgeons; image $\mathrm{E}(+5 \mathrm{~mm})$ received better scores from dental surgeons compared with the dental students and laypersons; image $\mathrm{F}(-10 \mathrm{~mm})$ received better scores from the dental students and laypersons, compared with the dental surgeons; image $\mathrm{G}(+10 \mathrm{~mm})$ received better scores from the dental surgeons compared with the dental students. Differences between the sexes were tested in the mean scores for each group (dental surgeons, dental students and laypersons), and no significant difference was observed ( $p>0.05$; Mann-Whitney test) in any of the images. This shows that the perception of the different groups evaluated was independent of sex.

\section{Outcome: Desire to undergo surgery}

In general, the images $\mathrm{A}(+15 \mathrm{~mm})$ and $\mathrm{D}(-15 \mathrm{~mm})$ were those that most induced the desire for corrective surgery, whereas image B $(-5 \mathrm{~mm})$ was the one that least induced the desire to undergo surgery (Figure 4). Table 3 shows the prevalence of the desire for corrective surgery for each image presented and its association with the studied groups. The Poisson regression model adjusted for sex showed that the probability of having the desire to undergo corrective surgery differed among the groups for images B ( -5 $\mathrm{mm}), \mathrm{E}(+5 \mathrm{~mm}), \mathrm{G}(+10 \mathrm{~mm})$ and $\mathrm{H}(0 \mathrm{~mm})$ : 
image $\mathrm{B}(-5 \mathrm{~mm})$, the desire to undergo surgery was 73\% lower in the dental students compared with the dental surgeons; image $\mathrm{E}(+5 \mathrm{~mm})$, the desire to undergo surgery was approximately five times and ten times greater in the dental students and laypersons, respectively, compared with the dental surgeons; image $\mathrm{G}(+10 \mathrm{~mm})$, the desire to undergo surgery was two times higher in the dental students compared with the dental surgeons; image $\mathrm{H}(0 \mathrm{~mm})$, the desire to undergo surgery was approximately two times and three times higher in the dental students and laypersons, respectively, compared with the dental surgeons.

\section{DISCUSSION}

Mentoplasty is an important adjuvant surgical procedure for the correction of facial disharmony and profile imbalance [8]. Although it is often seen by surgeons as a secondary procedure after orthognathic surgery or rhinoplasty, the configuration of the chin is an important component of facial esthetics [9].

When the chin is appropriate in size, shape and position, it may enhance the normal harmony and symmetry of the face, camouflaging the relationship of the mandible showing it to be ideal. However, when inadequate, it may significantly diminish the pleasant shape of a face or good surgical result, transmitting undesirable attributes. The chin is a reflection of the whole face, and together with the nose, is one of the main determinants of balance of the facial profile [9].

Facial analysis is an important prerequisite for revealing esthetic condition, however, it is a complicated task to perform. The shape of the human face mainly depends on the bony structures and soft tissues, these facial structures being highly influenced by age, sex, race and ethnicity [10]. In this context the aim of the present study was to evaluate the influence of mentoplasty with different degrees of retrusion and protrusion on the esthetic perception of dental surgeons, dental students and laypersons, in addition to determining whether or not the outstanding chin affects the perceived desire to undergo orthognathic surgery.

During the bibliographic search, no study that evaluated the requisites proposed in the present study was found, therefore the results here described are unprecedented in the literature.

Conducting studies with a view to evaluating the degree of influence of diverse requisites that compose facial and dental morphology and esthetics is feasible, using modifications in photographs, with the aid of computer software programs. In the literature, various studies are found, using this same methodology here presented to evaluate esthetic requisites both of the teeth and facial pattern $[8,11-16]$.

At present, various studies have paid attention to the esthetic perception of laypersons and dental surgeons $[11,12,14,17-20]$, which is of much relevance in the society in which we live, in order to establish a good relationship between treatments to be performed and patient satisfaction.

Clinically, orthodontists diverge with regard to the use of photographs, silhouettes and cephalometric tracings for evaluating the esthetics of the facial profile [2]. In the present study, silhouettes were used, because with the use of these, factors that influence the observer's concept of attractiveness, such as the color of the skin, eyes and facial marks, among others, may be removed.

When evaluating the esthetic attractiveness of facial profiles of Negros using photos and silhouettes among negro and white individuals (Pithon et al., 2013) [2], it was verified that there are no differences with regard to these methods of evaluation.

When analyzing the results of the present study, it could be perceived that all the interviewees were able to note differences in the images, demonstrating that the facial profile of individuals interfere in the esthetic perception of persons. The choice of the ideal profile as the 
most esthetic and attractive was unanimous, and both the profile with extreme mandibular prognathism and retrognathism were considered the least attractive, a result that corroborates the findings of Modarai et al. (2013) [6].

Naini et al. (2012)[5] and Kuroda et al.(2009)[21], indicated that the greater the sagittal deviation, the less attractive the image becomes. According to them, worse effects are seen when the chin is more protrusive than retracted, a datum also observed in the present study.

The majority of the interviewees declared the desire for surgical correction if that were their own profile, thus one may perceive how unpleasant it is to have this type of facial profile. In general, the desire to undergo surgery was lower among the professionals than among the laypersons and dental students. This may be observed in Table 3 , and may indicate that the more knowledge one has about the surgical procedures, their risks and discomforts, the less the desire to submit oneself to these. This result corroborates the findings of Cochrane who found significant differences between laypersons and clinicians with regard to the attractiveness of the facial profile.

The results from the present study even further reflect the need for drawing up a treatment plan based on facial analysis and the patient's wishes. It is always important to show the patient his/her facial profile photograph before beginning treatment, so that the individual can consider whether or not it is convenient to undergo surgical correction associated with the orthodontic treatment that will be started.

\section{CONCLUSION}

By conducting this study, it could be concluded that:

- prognathic and retrognathic facial profiles are unpleasant and perceptible to the dental surgeon, dental student and layperson;

- the majority of the interviewees declared the desire to undergo surgical correction if the image in question were of their own profile.

\section{REFERENCES}

1. Paiva JB, Attizzani MF, Miasiro Junior H, Rino Neto J. Facial harmony in orthodontic diagnosis and planning. Braz Oral Res. 2010;24:52-7.

2. Pithon MM, Silva IS, Almeida I0, Nery MS, de Souza ML, Barbosa G, et al. Photos vs silhouettes for evaluation of profile esthetics between white and black evaluators. Angle Orthod. Angle Orthod. 2014 Mar;84(2):231-8. doi: 10.2319/051513-373.1. Epub 2013 Aug 19.

3. Pithon MM, Andrade D, Fernandes I, Mendes J, Nunes K, Michele L, et al. Influence of malocclusion on social perceptions of adolescents at public and private schools. Eur Arch Paediatr Dent. 2014 Feb;15(1):37-43.

4. Pithon MM, Santos AM, Viana de Andrade AC, Santos EM, Couto FS, da Silva Coqueiro R. Perception of the esthetic impact of gingival smile on laypersons, dental professionals, and dental students. Oral Surg Oral Med Oral Pathol Oral Radiol. 2013;115:448-54.

5. Naini FB, Donaldson AN, McDonald F, Cobourne MT. Influence of chin height on perceived attractiveness in the orthognathic patient, layperson, and clinician. Angle Orthod. 2012;82:88-95.

6. Modarai F, Donaldson JC, Naini FB. The influence of lower lip position on the perceived attractiveness of chin prominence. Angle Orthod. 2013;83:795-800.

7. Bracaglia R, Tambasco D, Gentileschi S, D'Ettorre M. A simple procedure to facilitate chin implants placement via submental approach. J Plast Surg Hand Surg. 2013;47:200-3.

8. Wolfart S, Brunzel S, Freitag S, Kern M. Assessment of dental appearance following changes in incisor angulation. Int J Prosthodont. 2004;17:150-4

9. Cingi C, Songu M, Thomas JR. Augmentation mentoplasty with osteocartilaginous nasal graft. Otolaryngol Head Neck Surg. 2010;143:549-53.

10. Strauss RA, Abubaker A0. Genioplasty: a case for advancement osteotomy. J Oral Maxillofac Surg. 2000;58:783-7.

11. Kokich VO, Kokich VG, Kiyak HA. Perceptions of dental professionals and laypersons to altered dental esthetics: asymmetric and symmetric situations. Am J Orthod Dentofacial Orthop. 2006;130:141-51.

12. Moore T, Southard KA, Casko JS, Qian F, Southard TE. Buccal corridors and smile esthetics. Am J Orthod Dentofacial Orthop. 2005;127:208-13; quiz 61.

13. Parekh S, Fields HW, Beck FM, Rosenstiel SF. The acceptability of variations in smile arc and buccal corridor space. Orthod Craniofac Res. 2007;10:15-21.

14. Parekh SM, Fields HW, Beck M, Rosenstiel S. Attractiveness of variations in the smile arc and buccal corridor space as judged by orthodontists and laymen. Angle Orthod. 2006;76:557-63.

15. Pithon MM, Bastos GW, Miranda NS, Sampaio T, Ribeiro TP, Nascimento $\mathrm{LE}$, et al. Esthetic perception of black spaces between maxillary central incisors by different age groups. Am J Orthod Dentofacial Orthop. 2013;143:371-5.

16. Thomas JL, Hayes C, Zawaideh S. The effect of axial midline angulation on dental esthetics. Angle Orthod. 2003;73:359-64.

17. Abu Alhaija ES, Al-Shamsi NO, Al-Khateeb S. Perceptions of Jordanian laypersons and dental professionals to altered smile aesthetics. Eur J Orthod. 2011;33:450-6.

18. Chen T, Khadka A, Hsu Y, Hu J, Wang D, Li J. How to achieve a balanced and delicate lower third of the face in Orientals by mandibular contouring. J Plast Reconstr Aesthet Surg. 2013;66:47-56. 
19. Jornung J, Fardal 0. Perceptions of patients' smiles: a comparison of patients' and dentists' opinions. J Am Dent Assoc. 2007;138:1544-53; quiz 613-4.

20. Pithon MM, Santos AM, Couto FS, de Freitas LM, Coqueiro Rda S. Comparative evaluation of esthetic perception of black spaces in patients with mandibular incisor extraction. Angle Orthod. 2012;82:806-11.
21. Kuroda S, Sugahara T, Takabatake S, Taketa H, Ando R, TakanoYamamoto T. Influence of anteroposterior mandibular positions on facial attractiveness in Japanese adults. Am J Orthod Dentofacial Orthop. 2009;135:73-8.

\section{Matheus Melo Pithon}

\section{(Corresponding address)}

Av. Otávio Santos, 395, sala 705, Centro Odontomédico Dr. Altamirando da Costa Lima, Bairro Recreio, CEP 45020-750 - Vitória da Conquista - Bahia, Brazil 